\title{
Water Quality Enhancement in Ponds Using Baffles, Burullus in Egypt as a Case Study
}

\author{
Diaa Seif, $M S$ \\ Medhat Moustafa, PhD \\ Sanitary Engineering Department, \\ Faculty of Engineering, Alexandria University. \\ Mohamed Soliman, PhD \\ Irrigation and Hydraulic Engineering Department, \\ Faculty of Engineering, AAST.
}

Doi: 10.19044/esj.2018.v14n18p361 URL:http://dx.doi.org/10.19044/esj.2018.v14n18p361

\begin{abstract}
This study investigated the simulation of hydrodynamics water quality in waste stabilization ponds (WSPs) after using baffles. The major functions performed by baffles are to reduce hydraulic short-circuiting and to provide a submerged surface, which can encourage the growth of attached biomass. Attached biomass growing on the surface of the baffles could increase the total mass of organisms in the pond, thus improve the treatment efficiency and therefore reduce the eutrophication rate in the pond such as $\mathrm{NH}_{3}-\mathrm{N}, \mathrm{NO}_{3}-\mathrm{N}$ $\& \mathrm{PO}_{4}-\mathrm{P}$. In this research, mathematical model (MIKE21) developed by (DHI), was formulated to simulate water quality parameter. The study applied on Burullus Lake, which is the second largest northern lake in Egypt, which belongs to high eutrophic lake type and suffers from several problems. Results showed that there is a significant variance between the rate of values without and after making baffles. The findings indicated that the percentage removal of $\mathrm{NH}_{3}-\mathrm{N}, \mathrm{NO}_{3}-\mathrm{N} \& \mathrm{PO}_{4}-\mathrm{P}$ are $(51.8,43.7 \& 40.1 \%)$ respectively in the case of no overlap between baffles, to be $(83.4,94.3 \& 89.6 \%)$ in the case of overlap ratio 0.95 at the high temperature. This result suggests that the overlap between baffles is more efficient to reduce the eutrophic rate in the water. In conclusion, waste ponds can be improved easily and economically to be more efficient by making baffles.
\end{abstract}

Keywords: Hydrological, Geometrical, Computational fluid dynamic, Modelling, Baffles 


\section{Introduction}

There are many methods of water resource recovery facility; several techniques are used to treat domestic wastewater. These can be classified into two groups: conventional and non-conventional treatment facility. The former has high-energy requirements, which includes trickling filters, activated sludge systems, biodisc rotators and aerated lagoons. The latter is solely dependent on natural purification processes include constructed wetlands (CW) and waste stabilization ponds (WSPs). Among these technologies, the widely recommended ones for developing countries are the WSPs.

Waste stabilization ponds are biological treatment systems, which processes and operations are highly dependent on the environmental conditions such as temperature, wind speeds and light intensity which highly variable and any given combination of these environmental parameters (Gawasiri, 2003).

In this research study, Burullus Lake in Egypt has been chosen to apply the baffle scenario. This lake classified as a high eutrophic lake type because there are nine sources inflows into Burullus Lake, discharging approximately 3904 million $\mathrm{m}^{3} /$ year, including agricultural, industrial and domestic wastewater (El-Zeiny \& El-Kafrawy, 2016; El-Shinnawy, 2003). The High rate of Eutrophication such as Ammonia $\left(\mathrm{NH}_{3}-\mathrm{N}\right)$ resulting acceleration in biological productivity (growth of algae and weeds) so that's lead to low water transparency and depletion in dissolved oxygen rate causing death large quantities of fish (Chislock et al. 2013).

This study was conducted to a) study the possibility of reducing the Eutrophic rate of $\left(\mathrm{NH}_{3}-\mathrm{N}\right),\left(\mathrm{NO}_{3}-\mathrm{N}\right)$ and $\left(\mathrm{PO}_{4}-\mathrm{P}\right)$ at different temperature by using the simple way of baffles scenario, b) know the effect of the baffle on the water velocity, c) identify the importance of presence overlap between baffles, and d) simulate the water quality in Burullus Lake after making baffles.

\section{Background}

\section{Treated pond system}

Waste stabilization ponds and constructed wetlands are increasingly applied for domestic wastewater treatment as they can offer completely natural purifying process. Their designer comes from many different backgrounds or disciplines, including civil engineering, environmental engineering, microbiology, chemical engineering, soil science, or natural resources management. There are several types of (WSPs), Anaerobic, facultative, aerobic (maturation) ponds (AFM, 1988).

Anaerobic ponds are built to a depth of 2 to $5 \mathrm{~m}$ and have a relatively short detention time of 1 to 7 days. Facultative ponds should be constructed to a depth of 1 to $2.5 \mathrm{~m}$ and have a detention time between 5 to 30 days. Aerobic 
ponds are usually between 0.5 to $1.5 \mathrm{~m}$ deep (Burullus Lake the case study) with a detention time of 15 to 20 days. If used in combination with algae and/or fish harvesting, this type of pond is effective at removing the majority of nitrogen and phosphorus from the effluent (Eddy, 2003).

\section{Baffles performance}

For the purposes of this research study, baffles will be considered as a physical restriction.

Several investigators have used baffles in waste stabilization ponds and indicated that the performance of the pond was affected to the better side. The arrangement of the baffles is usually designated by the type of hydraulic characteristics and the detention time needed to improve the water quality. The mean flow path through a pond with over-and-under baffles would be longer than in an unbaffled pond and the velocity of the wastewater would increase as a result (Mara, 2005).

\section{Modelling Application}

The CFD (computational fluid dynamics) modelling, which was selected for the present study, is surface-water modelling system (Mike21) Mike is a comprehensive environment for two-dimensional hydrodynamic \& ecological modelling. The numerical model of (Mike21) is established according to the solution of the two or three-dimensional incompressible Reynolds averaged Navier-Stokes equations (Schnoor, 1996).

\section{Materials \& Methods}

This research study applied the baffles scenario at two cases the first is a simple regular shape boundary with the different baffles situation. The second case is applying the baffles in the Burullus Lake as a case study showing the effectiveness of them at the water quality.

\section{Simple case}

A simple scenario case with different conditions of overlap between baffles were founded as shown in figure 1
(a) No baffle case
(b) Baffles without overlap between.
(c) Baffles with an overlap ratio $\approx 0.25$.
(d) Baffles with an overlap ratio $\approx 0.50$.
(e) Baffles with an overlap ratio $\approx 0.80$.
(f) Baffles with an overlap ratio $\approx 0.95$. 

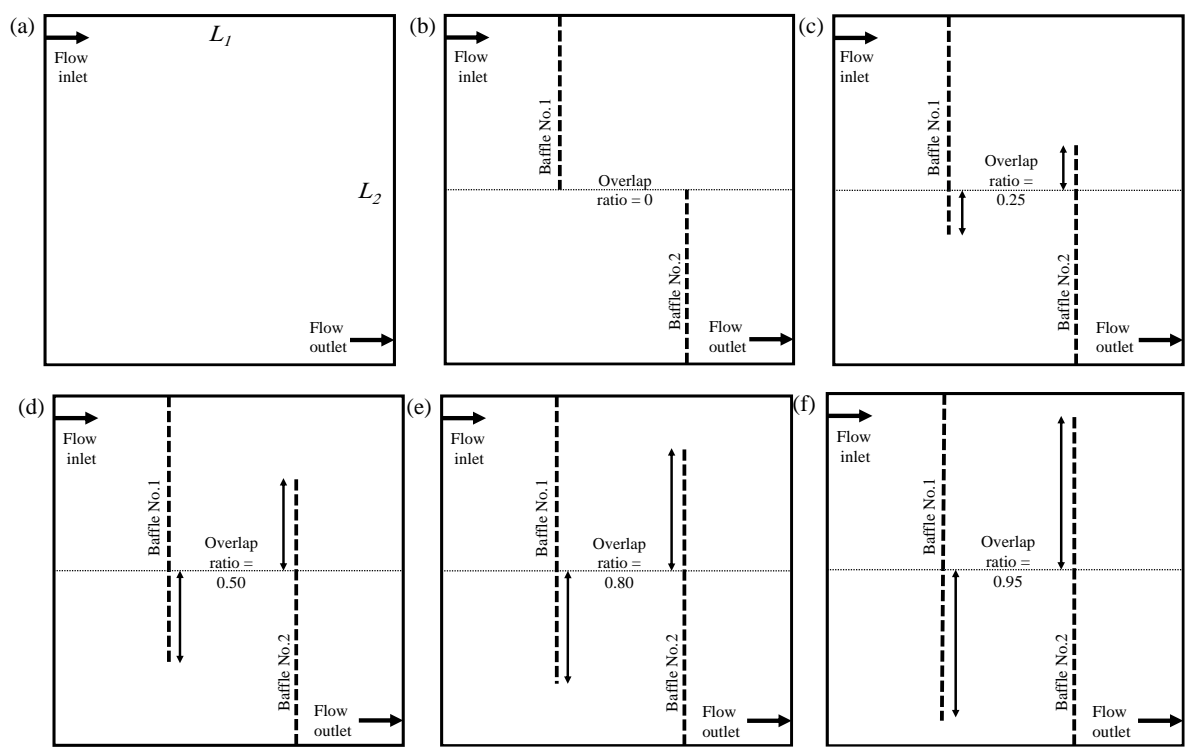

Figure 1: Different scenario simulation of baffles in regular shape boundary.

The operated boundary conditions for the present study were chosen as follows:

Average flow rate inlet $\left(100 \mathrm{~m}^{3} / \mathrm{hr}\right)$, depth $(1.5 \mathrm{~m})$, the boundary length $(L 1=L 2)$, eutrophic water characteristics was assumed to be as the case study of the drain sources in the Burullus lake: influent concentration of $\mathrm{NH}_{3}-\mathrm{N}=5.2$ $\mathrm{mg} / \mathrm{l}, \mathrm{NO}_{3}-\mathrm{N}=1.5 \mathrm{mg} / \mathrm{l}, \mathrm{PO}_{4}-\mathrm{P}=1.5 \mathrm{mg} / \mathrm{l}$. The average detention time from 5 to $8 \mathrm{hr}$.

\section{Study Area}

The Burullus Lake water is brackish nature, it is a mixture of drain and seawater is the two main sources to the lake. Seepage from the cultivated lands and rainfall in winter are secondary sources. Generally, the Southern part of the lake is more affected by the drainage. Water Northern parts and the Eastern basin are near from the seawater source, which called El-Boughaz (Figure 2). Burullus Lake is located in the North-western region of the Nile Delta; i.e., Longitude $30^{\circ} 33^{\prime}-31^{\circ} 07^{\prime} \mathrm{E}$ and latitude $31^{\circ} 22^{\prime}-31^{\circ} 26^{\prime} \mathrm{N}$ (El-Zeiny \& ElKafrawy, 2016). The lake has dimensions of $47 \mathrm{~km}$ in length, $6-14 \mathrm{~km}$ in width, and $0.4-2.1 \mathrm{~m}$ in depth, with an approximate surface area of $410 \mathrm{Km}^{2}$ (Shaltout, 2017). A finite-element model was used to cover the irregular domain of Burullus Lake with 19509 elements and 9000000 nodes (Figure 2). Bathymetric charts were presented using an average water depth for a unit area of $150 \mathrm{~m} \times 150 \mathrm{~m}$, and the model domain was discretized into non-overlapping elements/cells. The Courant number was selected as 0.8 based on the mesh resolution, field velocity, and $100 \mathrm{sec}$ time interval $(2.7 \times 106$ time steps). Wind friction was determined from the observation of Egyptian Meteorological 
Authority, according to the wind speed; e.g., Wind friction of 0.001255 at 7 $\mathrm{m} / \mathrm{s}$. The average drains flow rate and the values of $\mathrm{NH}_{3}-\mathrm{N}, \mathrm{NO}_{3}-\mathrm{N} \& \mathrm{PO}_{4}-\mathrm{P}$ for one year, according to the Egyptian Environmental Affairs Agency (EEAA) and many previous investigation studies summarized in (Table1).

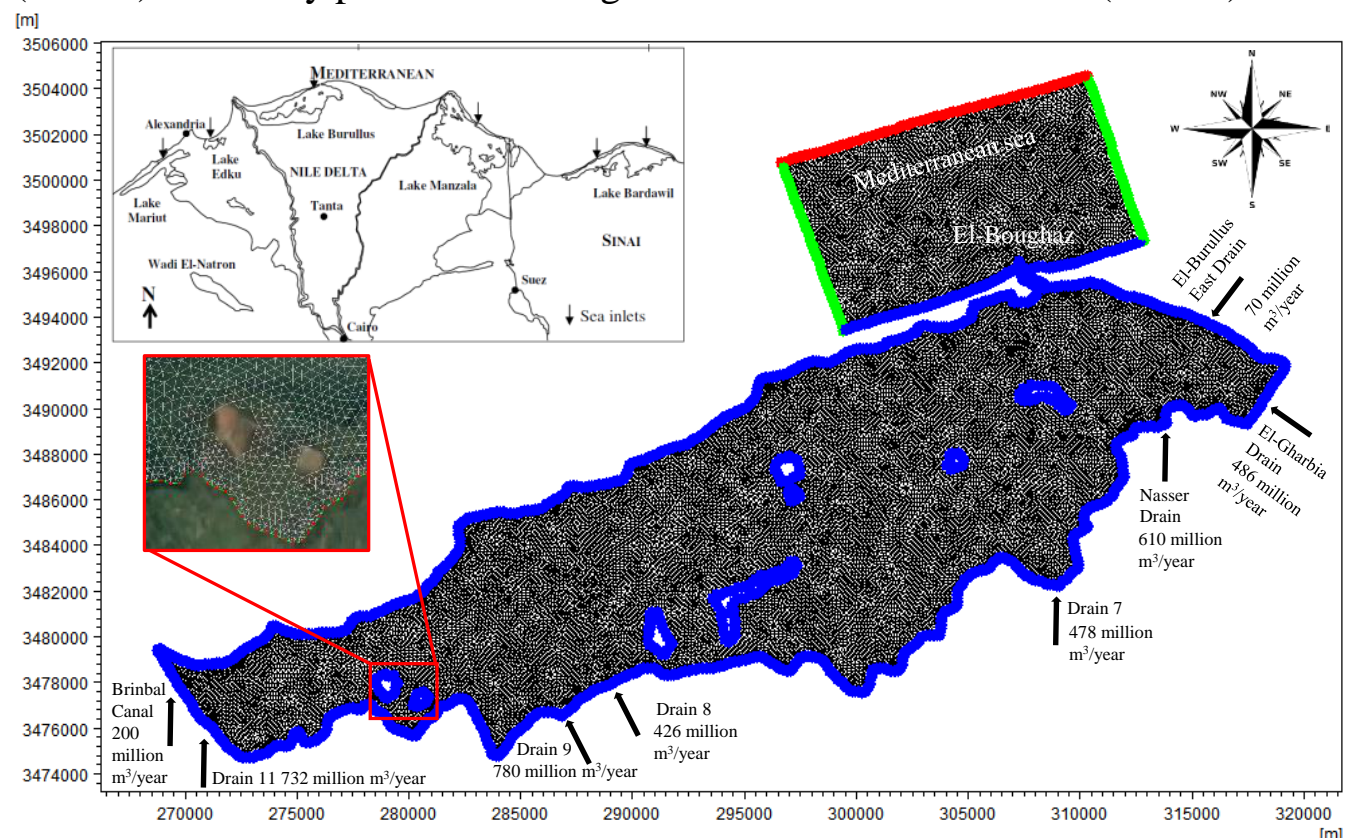

Figure 2: 2D visualization of a computational mesh of Burullus Lake and its location.

Table 1: Average drains flow and Eutrophic parameters in Burullus

\begin{tabular}{|c|l|r|r|r|r|}
\hline No. & \multicolumn{1}{|c|}{ Drain } & $\begin{array}{c}\text { Inflow rate million } \\
\mathbf{3} / \mathbf{y e a r}\end{array}$ & $\begin{array}{c}\mathbf{N H}_{\mathbf{3}}-\mathbf{N} \\
\mathbf{m g} / \mathbf{l}\end{array}$ & $\begin{array}{c}\mathbf{N O}_{\mathbf{3}}-\mathbf{N} \\
\mathbf{m g} / \mathbf{l}\end{array}$ & $\begin{array}{c}\mathbf{P O}_{\mathbf{4}}-\mathbf{P} \\
\mathbf{m g} / \mathbf{l}\end{array}$ \\
\hline 1 & EL-Burullus & 70 & 3.4 & 1.55 & 0.26 \\
\hline 2 & EL-Gharbia & 486 & 5.8 & 2.13 & 0.35 \\
\hline 3 & Nasser & 610 & 4.3 & 1.24 & 0.16 \\
\hline 4 & Drain 7 & 478 & 3.6 & 1.80 & 0.34 \\
\hline 5 & Drain 8 & 426 & 7.5 & 2.25 & 1.24 \\
\hline 6 & Drain 9 & 780 & 8.2 & 1.95 & 0.85 \\
\hline 7 & Drain 11 & 732 & 6.6 & 1.65 & 0.53 \\
\hline 8 & Brimbal & 200 & 5.4 & 1.90 & 0.21 \\
\hline
\end{tabular}

The scenario of the baffles overlap has been applied in the model simulation, it's ranged to be from (0.20 to 0.30) case as shown in Figure 3 . This range is due to that the width and the edges of the Burullus Lake are irregular. The water path direction is related to that the high water level in the lake from the drains during most months leads to flow towards the Mediterranean Sea. 


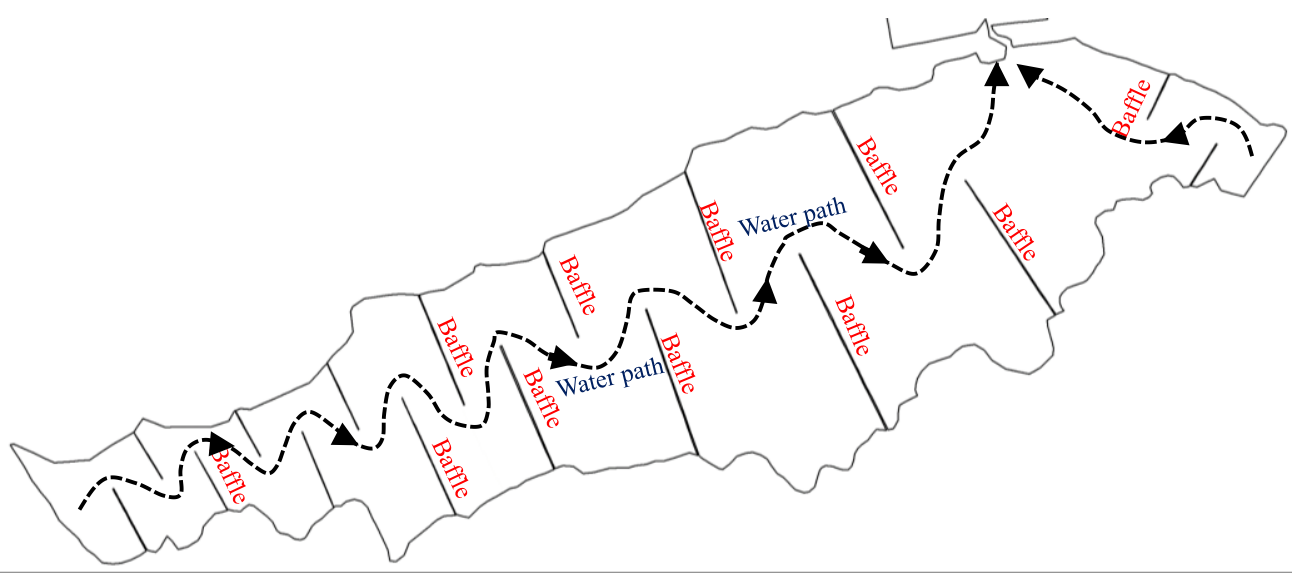

Figure 3: Baffles distribution with overlap ratio between $(0.20-0.30)$ and the water path direction in the Burullus Lake.

\section{Results and Discussion}

\section{Model calibration and validation}

Calibration consisted of iterative adjustments to model parameters until the model results agreed with the measured data. The calibrated HD model parameters included the high order equation technique for time integration and space discretization; a CFL number of 0.8 ; constant bed resistance Manning's n of 0.02 to 0.035 for the Lake; minimum temp $5^{\circ} \mathrm{c}$ and $\max 40^{\circ} \mathrm{c}$; flow rate as discharge unit is $\mathrm{m}^{3} /$ day for each inlet source.

The ECO Lab model calibrated parameters included the MIKE 21/3 WQ with nutients; using Eulerian framework; high order equation technique for time integration and space discretization.

The $\mathrm{NH}_{3}-\mathrm{N}, \mathrm{NO}_{3}-\mathrm{N} \& \mathrm{PO}_{4}-\mathrm{P}$ coefficients used for calibration were nitrification 1 st order decay rate at $20^{\circ} \mathrm{C}(1.3$ per day), Half-saturation oxygen concentration $(2.1 \mathrm{mg} / \mathrm{l})$, Maximum oxygen production at noon $(10 \mathrm{mg} / \mathrm{l}$ per day $\left./ \mathrm{m}^{3}\right)$, Nitrate 1 st order denitrification rate at $20^{\circ} \mathrm{C}(0.32$ per day).

Figure 4 shows the comparison between the measured and modelsimulated of the water surface elevations at Burullus Lake over a calibration period approximately one year. Except for a slight overestimation of high and low tides near the end of the calibration period, the results shows a good agreement between data and model-simulated water elevations. The computed water surface elevations deviate from December 2014 to November 2015, the data set an average $-0.073 \mathrm{~m}$ (3\% of mean tidal range) at the sea entrance location and an average $-0.046 \mathrm{~m}$ ( $5 \%$ of mean tidal range) at the middle area in the Lake see figure 2. 

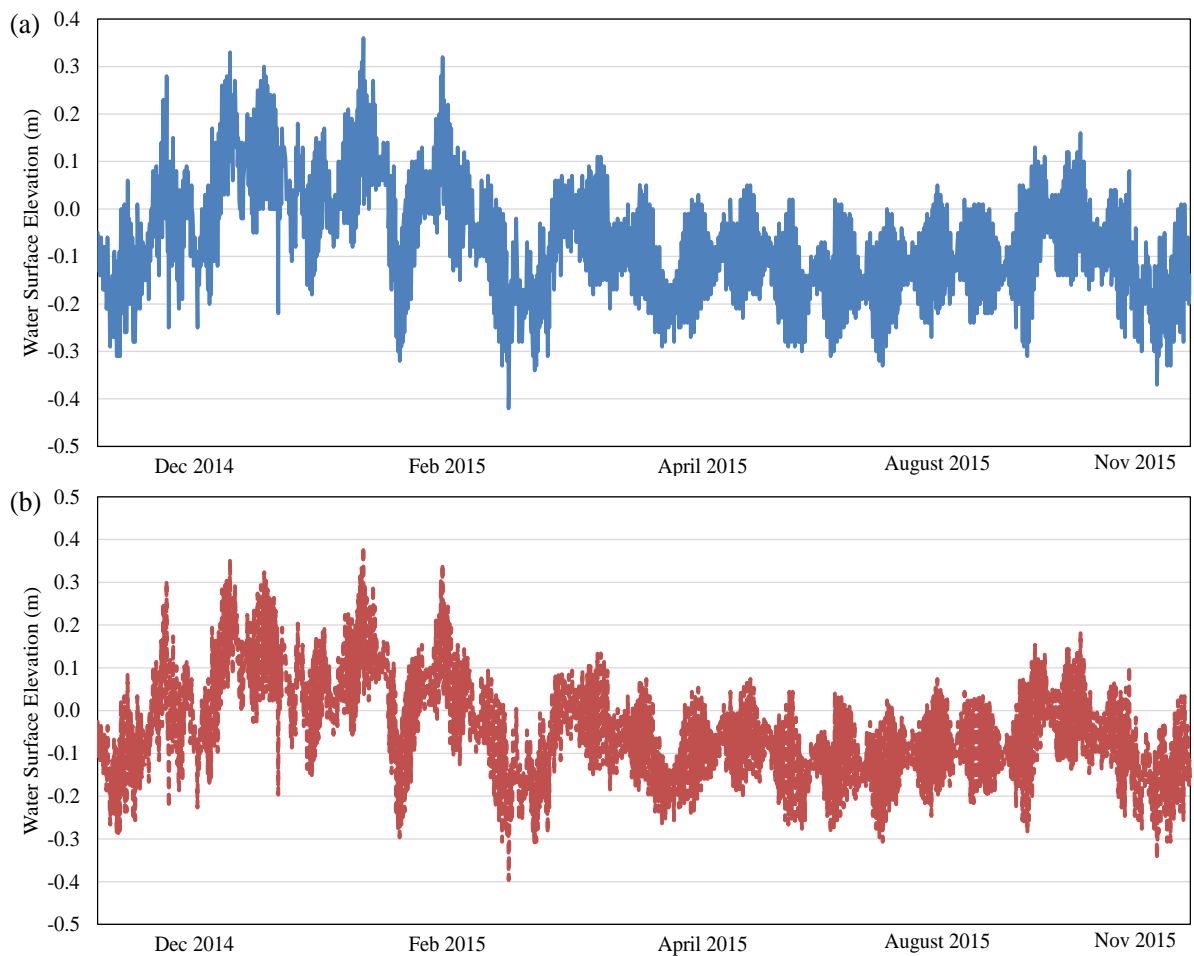

Figure 4: Comparison of Water Surface Elevations at Burullus Lake

(a) Measured (b) Simulated.

It was found that the coefficients of determination ( $\mathrm{R}^{2}$-values) of the water quality parameters were 0.64 for $\mathrm{NH}_{3}-\mathrm{N}, 0.62$ for $\mathrm{NO}_{3}-\mathrm{N}$ and 0.93 for $\mathrm{PO}_{4}-\mathrm{P}$.

The Slight variations, which were observed between the measured values and model results related to several reasons, most impurely that the dynamic simulation of eutrophication in a surface water system is very complicated and computationally intensive endeavor due to the time variations of a large number of chemical, biological, and biochemical processes; reaction rates; and external inputs (Park et al.1995). The complexity of the algal biology, the nonlinear interactions between nutrients and aquatic plants, and the interactions between the sediment bed and the water column (HydroQual, 1995).

\section{Model Simulation}

The model scenario simulation of the baffles on the simple boundary and Burullus Lake as a case study at the different temperature, showing little increasing in the water velocity and decreasing at the eutrophic rate of the $\left(\mathrm{NH}_{3}-\mathrm{N}, \mathrm{NO}_{3}-\mathrm{N} \& \mathrm{PO}_{4}-\mathrm{P}\right)$, the results are summarized in Table 2, which indicating the variation and the percent of removal for each parameter. 
The highest percentage of removal values appeared in the last case overlap 0.95 at temperature $35^{\circ} \mathrm{C}$, the values decreased from $(5.2 \mathrm{mg} / \mathrm{l}, 1.5$ $\mathrm{mg} / \mathrm{l} \& 1.5 \mathrm{mg} / \mathrm{l})$ to $(2.46 \mathrm{mg} / \mathrm{l}, 0.43 \mathrm{mg} / \mathrm{l} \& 0.33 \mathrm{mg} / \mathrm{l})$ for $\left(\mathrm{NH}_{3}-\mathrm{N}, \mathrm{NO}_{3}-\mathrm{N} \&\right.$ $\mathrm{PO}_{4}-\mathrm{P}$ ) respectively. This reduction of eutrophic rate related to the long water path circuiting, which gives the organisms in the water more time to digest the contaminants, and convert it from organic to inorganic (Khan, 2014).

Table 2: The summary results of the velocities \& Eutrophic parameters at different temperature after baffle scenario.

\begin{tabular}{|c|c|c|c|c|c|c|c|c|c|c|c|c|c|c|c|c|}
\hline & \multicolumn{16}{|c|}{ Water Temperature } \\
\hline & \multicolumn{4}{|c|}{$20^{\circ} \mathrm{C}$} & \multicolumn{4}{|c|}{$25^{\circ} \mathrm{C}$} & \multicolumn{4}{|c|}{$30^{\circ} \mathrm{C}$} & \multicolumn{4}{|c|}{$35^{\circ} \mathrm{C}$} \\
\hline & \multicolumn{16}{|c|}{ Case of no baffles } \\
\hline & Min & Max & Mean & $\begin{array}{l}\text { Percent of } \\
\text { removal \% }\end{array}$ & $\operatorname{Min}$ & $\operatorname{Max}$ & Mean & $\begin{array}{l}\text { Percent of } \\
\text { removal \% }\end{array}$ & Min & $\operatorname{Max}$ & Mean & $\begin{array}{l}\text { Percent of } \\
\text { removal \% }\end{array}$ & $\operatorname{Min}$ & $\operatorname{Max}$ & Mean & $\begin{array}{l}\text { Percent of } \\
\text { removal \% }\end{array}$ \\
\hline $\mathrm{NH}_{3}-\mathrm{N}$ & 4.34 & 5.20 & 4.722 & $16.5 \%$ & 4.27 & 5.20 & 4.71 & $18.0 \%$ & 3.76 & 5.20 & 4.19 & $27.7 \%$ & 2.85 & 5.20 & 3.68 & $45.2 \%$ \\
\hline $\mathrm{NO}_{3}-\mathrm{N}$ & 1.36 & 1.50 & 1.385 & $9.7 \%$ & 1.29 & 1.50 & 1.34 & $14.2 \%$ & 1.12 & 1.50 & 1.22 & $25.2 \%$ & 1.00 & 1.50 & 1.14 & $33.1 \%$ \\
\hline $\mathrm{PO}_{4}-\mathrm{P}$ & 1.37 & 1.50 & 1.443 & $8.7 \%$ & 1.30 & 1.50 & 1.39 & $13.6 \%$ & 1.22 & 1.50 & 1.34 & $18.5 \%$ & 1.05 & 1.50 & 1.19 & $29.7 \%$ \\
\hline \multirow[t]{2}{*}{ velocity $\mathrm{m} / \mathrm{sec}$} & 0.13 & 1.20 & 0.4962 & - & 0.14 & 1.20 & 0.52 & - & 0.15 & 1.20 & 0.53 & - & 0.17 & 1.20 & 0.60 & - \\
\hline & \multicolumn{16}{|c|}{ Case of two baffles (no overlap between baffle) } \\
\hline $\mathrm{NH}_{3}-\mathrm{N}$ & 4.18 & 5.20 & 4.64 & $19.6 \%$ & 3.71 & 5.20 & 4.21 & $28.7 \%$ & 3.43 & 5.20 & 3.93 & $34.1 \%$ & 2.51 & 5.20 & 3.39 & $51.8 \%$ \\
\hline $\mathrm{NO}_{3}-\mathrm{N}$ & 1.18 & 1.50 & 1.26 & $21.47 \%$ & 1.18 & 1.50 & 1.26 & $21.5 \%$ & 0.93 & 1.50 & 1.11 & $37.9 \%$ & 0.85 & 1.50 & 1.03 & $43.7 \%$ \\
\hline $\mathrm{PO}_{4}-\mathrm{P}$ & 1.25 & 1.50 & 1.35 & $16.5 \%$ & 1.10 & 1.50 & 1.26 & $26.5 \%$ & 1.03 & 1.50 & 1.18 & $31.6 \%$ & 0.90 & 1.50 & 1.05 & $40.1 \%$ \\
\hline \multirow[t]{2}{*}{ velocity $\mathrm{m} / \mathrm{sec}$} & 0.31 & 1.20 & 0.65 & - & 0.33 & 1.20 & 0.73 & - & 0.33 & 1.20 & 0.75 & - & 0.34 & 1.20 & 0.82 & - \\
\hline & \multicolumn{16}{|c|}{ Case of Two baffles (overlap between baffle ratio 0.25 ) } \\
\hline $\mathrm{NH}_{3}-\mathrm{N}$ & 4.03 & 5.20 & 4.51 & $22.5 \%$ & 3.42 & 5.20 & 3.97 & $34.2 \%$ & 3.19 & 5.20 & 3.72 & $38.7 \%$ & 2.3 & 5.2 & 3.2 & $56.5 \%$ \\
\hline $\mathrm{NO}_{3}-\mathrm{N}$ & 1.18 & 1.50 & 1.25 & $21.53 \%$ & 1.11 & 1.50 & 1.20 & $25.9 \%$ & 0.77 & 1.50 & 1.00 & $48.8 \%$ & 0.7 & 1.5 & 0.9 & $56.6 \%$ \\
\hline $\mathrm{PO}_{4}-\mathrm{P}$ & 1.16 & 1.50 & 1.28 & $22.8 \%$ & 0.97 & 1.50 & 1.15 & $35.3 \%$ & 0.85 & 1.50 & 1.03 & $43.3 \%$ & 0.8 & 1.5 & 0.9 & $49.0 \%$ \\
\hline \multirow[t]{2}{*}{ velocity $\mathrm{m} / \mathrm{sec}$} & 0.51 & 1.20 & 0.81 & - & 0.53 & 1.24 & 0.90 & - & 0.53 & 1.30 & 0.91 & - & 0.5 & 1.3 & 1.0 & - \\
\hline & \multicolumn{16}{|c|}{ Case of Two baffles (overlap between baffle ratio 0.50 ) } \\
\hline $\mathrm{NH}_{3}-\mathrm{N}$ & 3.76 & 5.30 & 4.31 & $29.0 \%$ & 3.13 & 5.30 & 3.74 & $40.9 \%$ & 2.93 & 5.30 & 3.54 & $44.7 \%$ & 1.95 & 5.30 & 2.94 & $63.2 \%$ \\
\hline $\mathrm{NO}_{3}-\mathrm{N}$ & 1.11 & 1.50 & 1.19 & $26.3 \%$ & 1.03 & 1.50 & 1.14 & $31.4 \%$ & 0.58 & 1.50 & 0.90 & $61.3 \%$ & 0.40 & 1.50 & 0.74 & $73.6 \%$ \\
\hline $\mathrm{PO}_{4}-\mathrm{P}$ & 1.01 & 1.50 & 1.15 & $32.5 \%$ & 0.79 & 1.50 & 1.00 & $47.6 \%$ & 0.67 & 1.50 & 0.88 & $55.1 \%$ & 0.62 & 1.50 & 0.80 & $58.6 \%$ \\
\hline \multirow[t]{2}{*}{ velocity $\mathrm{m} / \mathrm{sec}$} & 0.58 & 1.20 & 0.87 & - & 0.60 & 1.32 & 0.96 & - & 0.60 & 1.38 & 0.97 & - & 0.62 & 1.38 & 1.05 & - \\
\hline & \multicolumn{16}{|c|}{ Case of Two baffles (overlap between baffle ratio 0.80 ) } \\
\hline $\mathrm{NH}_{3}-\mathrm{N}$ & 3.54 & 5.30 & 4.09 & $33.2 \%$ & 2.77 & 5.30 & 3.38 & $47.8 \%$ & 2.53 & 5.30 & 3.13 & $52.3 \%$ & 1.53 & 5.30 & 2.46 & $71.1 \%$ \\
\hline $\mathrm{NO}_{3}-\mathrm{N}$ & 1.06 & 1.50 & 1.15 & $29.1 \%$ & 0.87 & 1.50 & 0.99 & $41.7 \%$ & 0.38 & 1.50 & 0.70 & $74.4 \%$ & 0.18 & 1.50 & 0.52 & $88.3 \%$ \\
\hline $\mathrm{PO}_{4}-\mathrm{P}$ & 0.88 & 1.50 & 1.01 & $41.6 \%$ & 0.56 & 1.50 & 0.78 & $62.4 \%$ & 0.45 & 1.50 & 0.66 & $69.9 \%$ & 0.37 & 1.50 & 0.54 & $75.6 \%$ \\
\hline \multirow[t]{2}{*}{ velocity $\mathrm{m} / \mathrm{sec}$} & 0.72 & 1.20 & 1.01 & - & 0.72 & 1.32 & 1.01 & - & 0.73 & 1.38 & 1.02 & - & 0.73 & 1.38 & 1.02 & - \\
\hline & \multicolumn{16}{|c|}{ Case of Two baffles (overlap between baffle ratio 0.95 ) } \\
\hline $\mathrm{NH}_{3}-\mathrm{N}$ & 3.24 & 5.30 & 3.79 & $38.8 \%$ & 2.14 & 5.30 & 2.75 & $59.7 \%$ & 1.64 & 5.30 & 2.25 & $69.0 \%$ & 0.88 & 5.30 & 2.46 & $83.4 \%$ \\
\hline $\mathrm{NO}_{3}-\mathrm{N}$ & 1.02 & 1.50 & 1.11 & $31.8 \%$ & 0.73 & 1.50 & 0.85 & $51.1 \%$ & 0.18 & 1.50 & 0.50 & $87.8 \%$ & 0.09 & 1.50 & 0.43 & $94.3 \%$ \\
\hline $\mathrm{PO}_{4}-\mathrm{P}$ & 0.72 & 1.50 & 0.86 & $51.7 \%$ & 0.52 & 1.50 & 0.74 & $65.1 \%$ & 0.25 & 1.50 & 0.46 & $83.6 \%$ & 0.16 & 1.50 & 0.33 & $89.6 \%$ \\
\hline velocity $\mathrm{m} / \mathrm{sec}$ & 0.72 & 1.20 & 1.01 & - & 0.72 & 1.32 & 1.01 & - & 0.73 & 1.38 & 1.02 & - & 0.73 & 1.38 & 1.02 & - \\
\hline
\end{tabular}

On the other hand, the percentage of the eutrophic rate at the most polluted area of the Burullus Lake, especially in the polluted zones which is near from drain $8 \& 9$ (Figure 2) shows significant improvement in the water quality. The values of $\left(\mathrm{NH}_{3}-\mathrm{N}, \mathrm{NO}_{3}-\mathrm{N} \& \mathrm{PO}_{4}\right)$ respectively decreased from $7.8 \mathrm{mg} / \mathrm{l}$ to $1.8 \mathrm{mg} / \mathrm{l}$ (Figure $5 \mathrm{a}$ ), from $2.1 \mathrm{mg} / \mathrm{l}$ to $0.46 \mathrm{mg} / \mathrm{l}$ (Figure $5 \mathrm{~b}$ ) and from $1.3 \mathrm{mg} / \mathrm{l}$ to $0.32 \mathrm{mg} / \mathrm{l}$ (Figure $5 \mathrm{c}$ ). At (Figure $5 \mathrm{~d}$ ) the dissolved oxygen (DO) rate in the lake has been dropped in some area, this is due to the bacteria decompose organic material to obtain energy for growth, break it down into simpler organic substances, and eventually convert it into inorganic 
substances. This decomposition exerts an oxygen demand and decrease the DO levels in the water (DL, 1999).

To improve the dissolved oxygen in these areas fixed or removable aerators should be found. There are many types of the aerators, which don't need high electricity and take its source power from the sunlight.

(a)

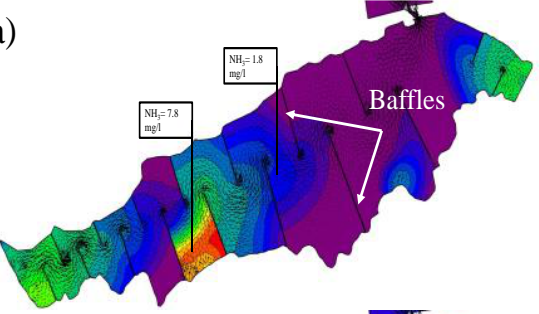

(c)

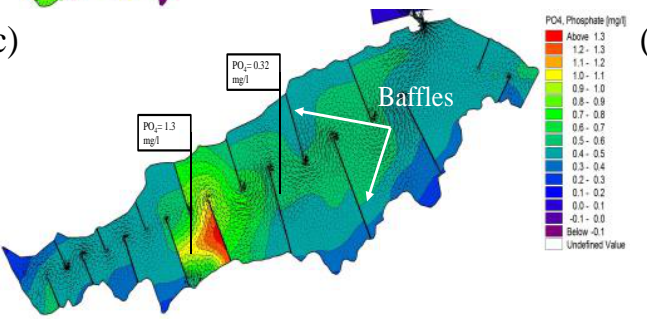

(b)

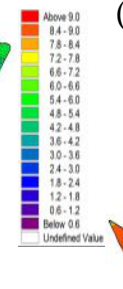

(d)

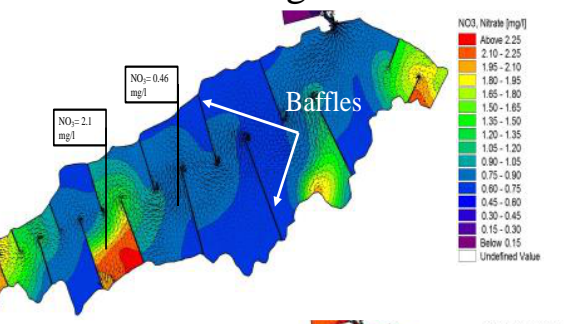

Figure 5: Simulation of water quality parameters of (a) $\mathrm{NH}_{3}-\mathrm{N}$, (b) $\mathrm{NO}_{3}-\mathrm{N}$, (c) $\mathrm{PO}_{4}-\mathrm{P}$ and

(d) DO after baffles scenario.

\section{Conclusion}

The results obtained through the present study showed that: increasing the length of the water path by applying baffle scenario in the pond increase in the removal efficiency of $\mathrm{NH}_{3}-\mathrm{N}, \mathrm{NO}_{3}-\mathrm{N}$ and $\mathrm{PO}_{4}-\mathrm{P}$ concentrations.

The overlap ratio between baffles is more efficient than no overlap, which leads to making a homogeneity in the waterbody and reduce the dead zone area in the lake, therefore improve water quality in the lake. Thus, increase the economic benefits from the lake to be serviceable in irrigation or fishpond.

\section{Acknowledgement}

The authors would like to thank Prof. Hamdy Abdel-Aziz, Dr. Mahmoud Nasr and Eng. Nour Seif for their kind support and my sincere gratitude for their effort.

Additionally, the authors wish to express their gratitude to all the staff of (EEAA) and National Institute of Oceanography for their important information and support. 


\section{References:}

1. AFM Air Force Manual. (1988). Domestic wastewater treatment. TM 5-814-3/AFM 88-11, Volume III, Washington, USA: Department of the army and air force.

2. Chislock, M., Doster, E., Zitomer, R., \& Wilson, A. (2013). Eutrophication: Causes, Consequences, and Controls in Aquatic Ecosystems. Nature Education Knowledge, 4 (4): 10.

3. DL, C. (1999). Phosphorus: a rate limiting nutrient in surface waters. Pollution Science, 78:674-682.

4. Eddy, M. (2003). Wastewater engineering; treatment and reuse. New York: McGraw-Hill.

5. El-Shinnawy. (2003). Impact of the catchment area on the hydrobiolocial environment of Borollus wet land, Egypt. Proceeding of 13th Environment Protection, 10-12 May 2003: Alex, pages. 27-44.

6. El-Zeiny, A. \& El-Kafrawy, S. (2016). Assessment of water pollution induced by human activities in Burullus Lake using Landsat 8 operational land imager and GIS. The Egyptian Journal of Remote Sensing and Space Science, In Press, volume 20, Pages S49-S56.

7. Gawasiri. (2003). Modern Design of Waste Stabilization Ponds in Warm Climates: Comparison with Traditional Design Methods. UK: MSc thesis, University of Leeds.

8. HydroQual (1995). A Water Quality Model for Massachusetts and Cape Cod Bays: Calibration of the Bays Eutrophication Model (BEM). Technical report, Hydro- Qual, Inc ., Mahwah, NJ .

9. Khan, M. N. (2014). Eutrophication: Challenges and Solutions. Volume II of Eutrophication: Causes, Consequences and Control. Springer, 17-27.

10. Mara, A. N. (2005). CFD (computational fluid dynamics) modelling of baffles for optimizing tropical waste stabilization pond systems. Water Science and Technology, 51, no. 12, pp.

11. Park , K. , Kuo, A. Y., Shen , J. , and Hamrick , J. M. (1995) . A Three - dimensional Hydrodynamic - Eutrophication Model (HEM3D): Description of Water Quality and Sediment Processes Submodels. The College of William and Mary, Virginia Institute of Marine Science. Special Report 327, 113 pp.

12. Schnoor, J. L. (1996). Environmental Modeling: Fate and Transport of Pollutants in Water, Air, and Soil. New York: John Wiley \& Sons.

13. Shaltout K. (2017). Reed Products from Lake Burullus, Egypt. The Wetland Book. Netherlands: Springer. 